\title{
簡易コーディングを用いた進化型人工神経回路網の 移動ロボット制御問題における性能検証*
}

\section{片田＼cjkstart喜章†・日高 拓哉 ${ }^{\dagger}$}

\author{
Simply Coded Evolutionary Artificial Neural Networks \\ on a Mobile Robot Control Problem*
}

Yoshiaki $\mathrm{KATADA}^{\dagger}$ and Takuya HIDAKA ${ }^{\dagger}$

\begin{abstract}
One of the advantages of evolutionary robotics over other approaches in embodied cognitive science would be its parallel population search. Due to the population search, it takes a long time to evaluate all robot in a real environment. Thus, such techniques as to shorten the time are required for real robots to evolve in a real environment. This paper proposes to use simply coded evolutionary artificial neural networks for mobile robot control to make genetic search space as small as possible and investigates the performance of them using simulated and real robots. Two types of genetic algorithm (GA) are employed, one is the standard GA and the other is an extended GA, to achieve higher final fitnesses. The results suggest the benefits of the proposed method.
\end{abstract}

\section{1. はじめに}

ロボットが実環境で自律的に振る舞うためには , シス テム自身が高い環境適応能力をもち，環境との相互作用 を通して自らの振舞いを獲得しなければならない $[1]$.こ のアプローチの一つに , 多点探索による高い解探索能力 が期待できる人工進化を用いて自律ロボットの制御器を 設計する進化ロボティクス $[2]$ がある . 進化ロボティク スでは, 制御器の評価は次の方法のどちらかで行われる .

a) 実環境でロボットを用いる [3]

b) シミュレーションを用いる [4]

a) の方法では，実環境でロボットを評価するため，実 時間がかかる . 人工進化で要する進化時間は数百世代か ら数千世代が一般的であり，膨大な時間がかかる．しか しながら，ロボットは実環境で評価されているため，光 の環境で適切に振る舞うことができる(光の進化時間内 に適応度が十分に改善されていることを仮定している）。 一方，b)の方法では, ロボットの評価にかかる時間を非 常に短くすることができる.しかし，シミュレーション で獲得した制御器を実ロボットに搭載する場合, シミュ レーションと実環境のギャップによってロボットが必ず

* 原稿受付 2009 年 4 月 22 日

†摂南大学 工学部 Faculty of Engineering, Setsunan University; 17-8 Ikeda-nakamachi, Neyagawa, Osaka 572-8508, JAPAN

Key Words: evolutionary artificial neural networks, evolutionary robotics, genetic algorithms, mobile robot.
しも実環境で適切に振る舞えるとは限らない $[5]$.この問 題に対しては多くのアプローチ $[4,6,7]$ が提案されている が, シミュレーションを用いることができる問題は, 乥 の環境およびロボットとの相互作用を適切にモデル化で きる問題に限られる . 進化ロボティクスのアプローチを より多くの問題に適用するには，a）実環境でロボットを 評価する方法，つまり，実環境でロボットを進化させる 時間を短縮する方法を考える必要がある.

これに対し，人工進化が解くべき問題の探索空間をで きるだけ小さく設定することが考えられる．つまり，遺伝 子長を短くすることができれば, どの進化アルゴリズムを 採用しても基本的には進化時間を短縮することが可能で あると期待できる . Floreano らは遺伝子長が非常に短く なるように人工神経回路網 (Artificial Neural Networks: $\mathrm{ANN})$ をコーディングし, 移動ロボット [8] や飛行船 ロボット [9] を実環境で進化させている . 参考文献 $[8$, 9] は遺伝子長を短く設定することを積極的に提案する 主旨の報告ではないが, 弚の意図するところは明らかで ある .

本論文ではこれらの文献 $[8,9]$ に動機付けられ，遺伝的 アルゴリズム (Genetic Algorithms: GA) の遺伝子長が 短くなるように, ANN の遺伝子コーディングとして考 えうる最も簡単なものを新たに 2 種類提案する . さらに 高い適応度を獲得するために , 拡張型 GAの一つであり ANN の進化に対し有効性が確かめられている Operon 
GA(OGA)[10-12]を適用し，Simple GA(SGA) を適用 する場合と比較する．乥して，この簡易コーディングを 用いた進化型人工神経回路網 (Evolutionary Artificial Neural Networks: EANN) をロボット制御問題の一つ である移動ロボットのゴール到達問題に適用し, 計算機 実験および実機実験において㚇の性能を検証する．

以下，第 2 章では，提案する簡易コーディングを用い たEANNについて述べる.第 3 章では, 自律移動ロボッ トのゴール到達問題に関して，提案手法の性能を計算機 実験において検証する．第 4 章では，実機実験において 第 3 章で得られた知見の検証を行う．第 5 章で本論文の まとめを示す .

\section{2. 簡易コーディングを用いた進化型人工 神経回路網}

本章では，GA の遺伝子長ができるだけ短くなるよ うにANN をコーディングする方法を述べる．以下， このコーディング法を用いるEANN を Simply Coded Evolutionary Artificial Neural Networks (SCEANN) とよぶことにする．

\subsection{ANN の構成}

中間層・出力層が相互結合された ANN を用いる.$i$ 番 目のニューロンの時刻 $t$ での出力は以下の式で表される.

$$
x_{i}(t)=f\left(\sum_{j} \omega_{i j} x_{j}(t-1)\right)
$$

ここで, $\omega_{i j}$ は $j$ 番目のニューロンから $i$ 番目のニューロ ンへの結合荷重, $f(x)$ はニューロンの出力関数であり, 本論文では $(2)$ 式で与えられるシグモイド関数を用いる.

$$
f(x)=\frac{1}{1+\exp (-x / T)}
$$

$T$ はシグモイド関数の傾きを決める正定数である .

一般的なEANNでは产の設計変数として, 各ニューロ ン間の結合荷重・各ニューロンのしきい值(シグモイド関 数を用いる場合は谷の傾き)・ニューラルネットの構造 · 学習則のいずれか，または弚のいくつかを扱う [13] . 本 論文では遺伝子長を短くするために, ニューラルネット の構造は固定とし, 学習は行わず, 結合荷重のみを GA の変数とする . また , シグモイド関数の傾きはパターン 認識などにおいて多く採用される $T=1$ とする $[14]$. 結 合荷重 $\omega_{i j}$ のコーディング法の詳細を以下で述べる .

\subsection{SCEANN}

\section{-SCEANN 1}

1.で述べた Floreano ら $[8,9]$ は，実ロボットの進化に 次のようなコーディング法を用いている.中間ノード数 を $N_{h}$ ，出カノード数を $N_{o}$ とし，2.1で述べた ANN の 構成から中間層または出力層に含まれる一つのノード に注目すると (Fig. 1), 遺伝子型全体は $\left(N_{h}+N_{o}\right)$ 個の ブロックから構成され，1 個のブロックは中間層・出力

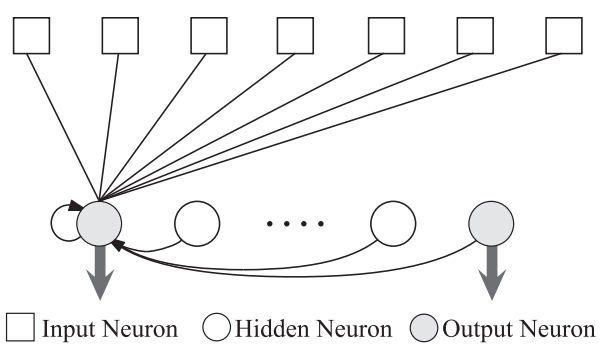

Fig. 1 Architecture of ANN for one block of a genotype

層に含まれる各ノードに関して定義される (Fig. 2) . ブ ロックの最初のビットは产のノードに入る全結合の符号 $\{+,-\}$ を表し, 残りのビットは $N_{s}$ 個の入カノード・ $N_{h}$ 個の中間ノードおよび $N_{o}$ 個の出カノードからの結合の 有無 $\{1,0\}$ を表す (Fig. 2(a)) . 本論文では, 結合の強さ は存在する結合すべてにおいて,$\left|\omega_{i j}\right|=1$ とする .した がって, 遺伝子長は $L_{1}=\left(N_{h}+N_{o}\right)\left(1+N_{s}+N_{h}+N_{o}\right)$ ビットとなる．

文献 $[8,9]$ では, ANN として Pulsed Neural Networks(PNN)[15] を用いているが , この PNN は GA の 設計変数以外に複数のパラメータを設定する必要がある. これらのパラメータはPNN の性能に大きく影響を与え ること, および, パラメータが少ない従来型の ANNの 方がより一般的な知見が得られると考えられるため, 本 論文では $2.1 て ゙$ て述べた ANN を用いることにする．

\section{-SCEANN 2}

SCEANN 2 では, Floreano らのコーディング法 (SCEANN 1) によって表現されるANN の構造に多 樣性を持たせるために, 中間・出カノードに入る結合光

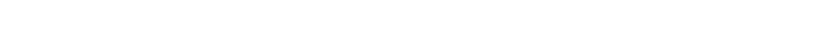
ドに入る結合の符号 $\{+,-\}$ および結合の有無 $\{1,0\}$ で構 成される (Fig. 2(b)) . SCEANN 1 と同樣に $\left|\omega_{i j}\right|=1$ と する . 遺伝子長は $L_{2}=2\left(N_{h}+N_{o}\right)\left(N_{s}+N_{h}+N_{o}\right)$ ビッ 卜となる .一般的に, $L_{2}$ は $L_{1}$ より長くなるが, 従来の コーディング法のように 1 変数に数ビットを要する方法 と比較すると, 弚の遺伝子長は短くなる. 本論文では, 簡易コーディングの枠組みの中でANN の構造の多樣性 を考慮したコーディング法の性能について検証するため， SCEANN 2 を提案する.

\section{-SCEANN 3}

SCEANN 3 ではSCEANN 1・SCEANN 2 で考えた 結合の有無をコーディングせず, 入力・中間・出カノー ドをすべて結合する．つまり，ブロックは光のノードに 入る結合の符号 $\{+,-\}$ のみで構成される (Fig. 2(c)) . SCEANN $1 \cdot$ SCEANN 2 と同樣に $\left|\omega_{i j}\right|=1$ とする. 遺伝子長は $L_{3}=\left(N_{h}+N_{o}\right)\left(N_{s}+N_{h}+N_{o}\right)$ ビットとな る. 以上より, 同じ $\left(N_{s}, N_{h}, N_{o}\right)$ で比較すると一般的に $L_{3}<L_{1}<L_{2}$ となる . 


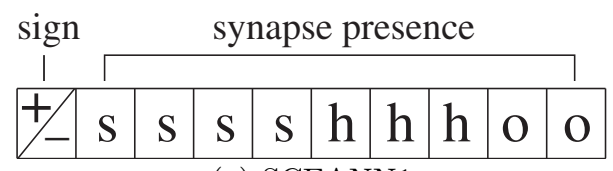

(a) SCEANN1

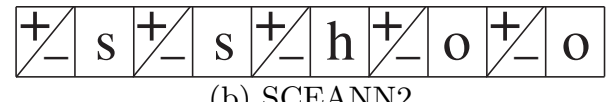

(b) SCEANN2

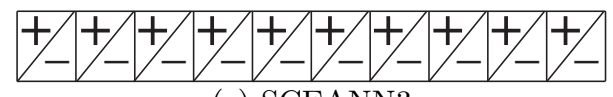

(c) SCEANN3

Fig. 2 Genetic representation of one block

\section{3. 計算機実験}

\section{1 タスクとモデル}

本章では, ロボット制御問題の一つであるゴール到達 問題において，2.で示したSCEANN の性能を検証する． Fig. 3 にゴール到達問題の概略を示す . ロボットに搭載 する距離センサは図に示す距離まで測定が可能であり， 物体までの距離と反比例する值を出力するように設定す る.ロボットの移動機構を左右二輪独立駆動型と仮定し， 光の中心位置 $(x, y)$ と姿勢 $\theta$ (Fig. 4$)$ は (3) 式のように更 新する。

$$
\begin{aligned}
& x_{t+1}=x_{t}+\frac{V_{R}+V_{L}}{2} \cos \theta_{t}+\omega_{x t+1} \\
& y_{t+1}=y_{t}+\frac{V_{R}+V_{L}}{2} \sin \theta_{t}+\omega_{y t+1} \\
& \theta_{t+1}=\theta_{t}+\frac{V_{R}-V_{L}}{2 R}+\omega_{\theta t+1}
\end{aligned}
$$

ここで， $V_{R}$ と $V_{L}$ は両車輪の周速度， $2 R$ は車輪間隔， $\omega_{[\cdot] t}$ はシステム誤差とする . (3) 式のシステム誤差は平 均 0 ・標準偏差 $\sigma$ の正規分布 $N(0, \sigma)$ で表されることが 知られている $[16]$. 本実験では, $\sigma$ は各ステップにおけ る移動量の $10 \%$ に設定する . モ一タ出力は ANN の出力 值 $x$ によって次のように与えられる: $V_{R, L}=V_{\max } \times x$. ここで, $V_{\max }$ は車輪の最大周速度とする．

ロボットは，より速くゴールに到達することを目的と

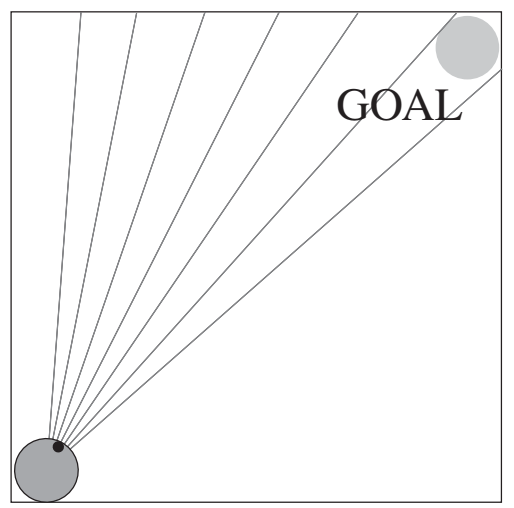

Fig. 3 Experimental setup for a simulated environment

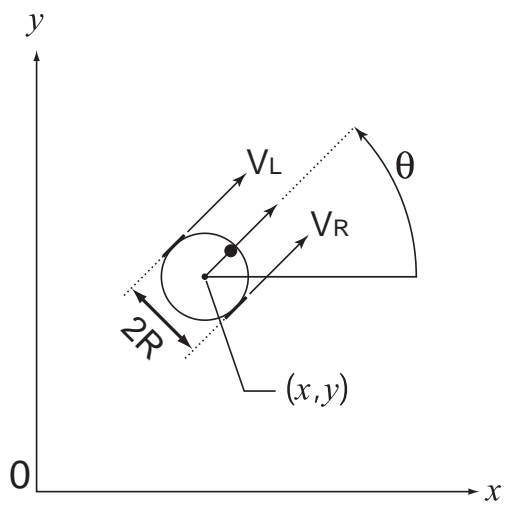

Fig. 4 Simulated model for a mobile robot

する . ロボットの初期位置を Fig. 3 の環境における左下 , ゴールの位置を右上にする . 試行はロボットがゴールに 到達するか , 到達せずに 200 ステップ経過したときに終 了する.ロボットの初期姿勢 $\theta_{0}$ を $0^{\circ}$ から $45^{\circ}$ ずつ変え た試行を 8 回行い, 次の適応度関数を用いて適応度を計 算する .

Fitness $=\frac{1}{\text { NumTrials }} \sum_{k=1}^{\text {NumTrials }}\left(1-\frac{\text { Step }}{\text { MaxStep }}\right)$

ここで，NumTrials は試行回数 (8)であり，MaxStep は 200 とする .

\section{2 実験設定}

ロボットの制御器として，2.で示した SCEANNを用 いる. 入カノード数は $N_{s}=\{1,2, \cdots, 7\}$ (距離センサ数， Fig. 5) , 中間ノード数は $N_{h}=\{1,2, \cdots, 5\}$ と変化させる . 出力ノード数は $N_{o}=2$ (モ一夕数) とする.一般的に入力 ノード数や中間ノード数は EANN の設計者か㵍題ごとに 決定する . 1.で述べたように本論文の目的は遺伝子長を 短くすることにあり， $N_{s} や N_{h}$ もできるだけ遺伝子長が 短くなるように設定することか望ましいため，ここでは 小さい值で害験を行うこととする .このように $\left(N_{s}, N_{h}\right)$ の弚れ光れを変化させて得られる知見は, 他の問題に本 手法を適用する際にも参考になると考えられる .

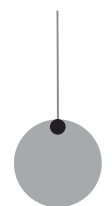

(a) 1

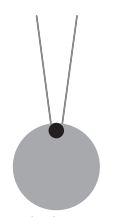

(b) 2

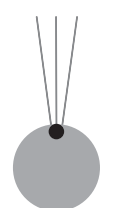

(c) 3

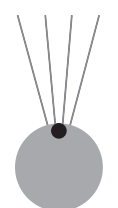

(d) 4

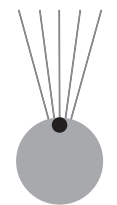

(e) 5

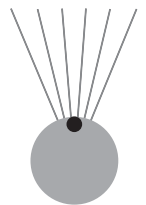

(f) 6

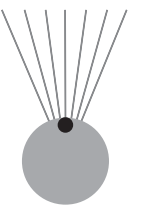

(g) 7
Fig. 5 Number of the proximity sensors equipped with a mobile robot 


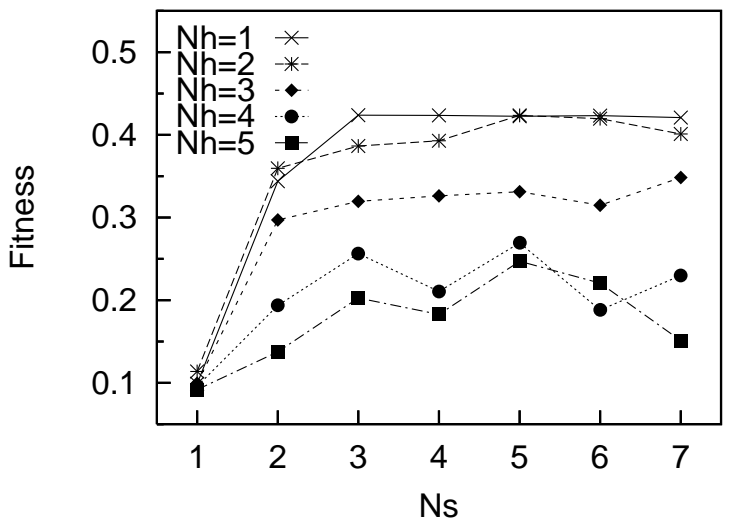

(a) SCEANN 1 by the SGA

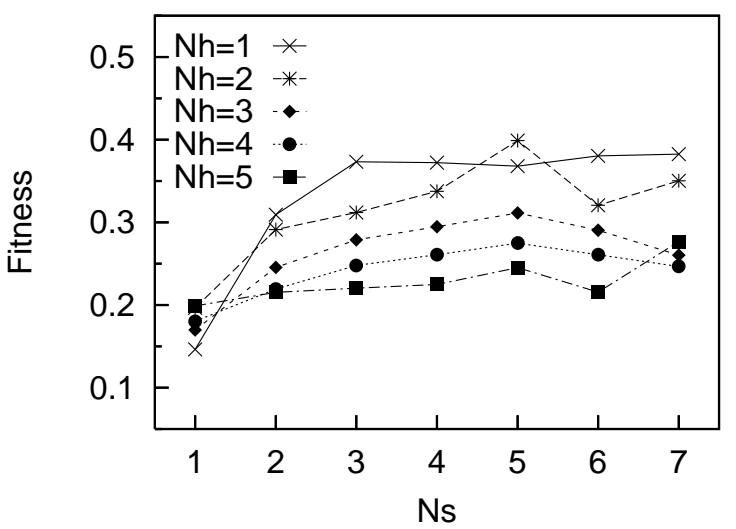

(c) SCEANN 2 by the SGA

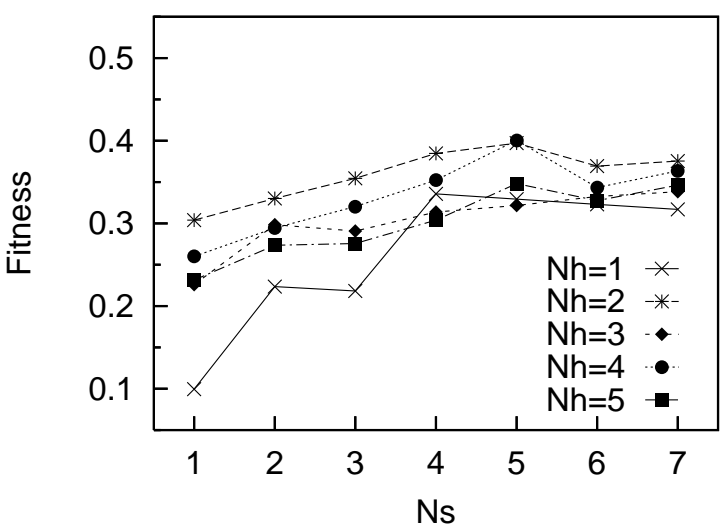

(e) SCEANN 3 by the SGA

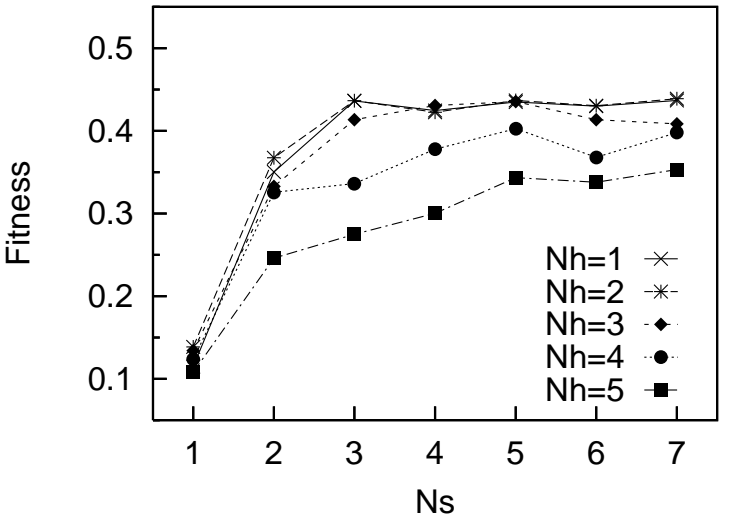

(b) SCEANN 1 by the OGA

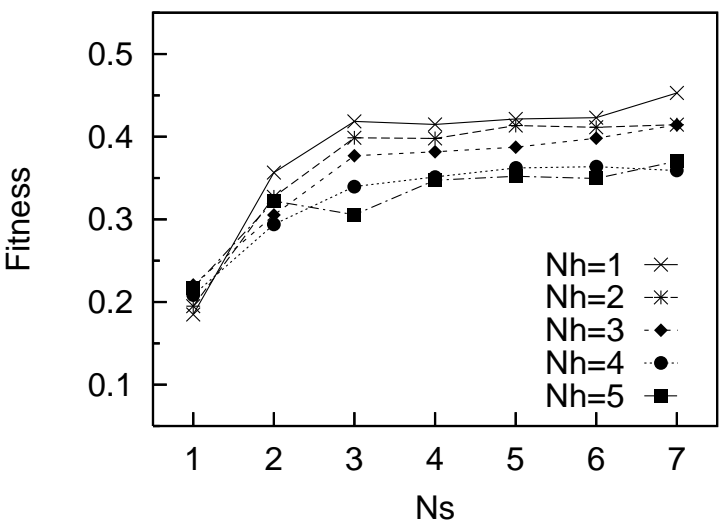

(d) SCEANN 2 by the OGA

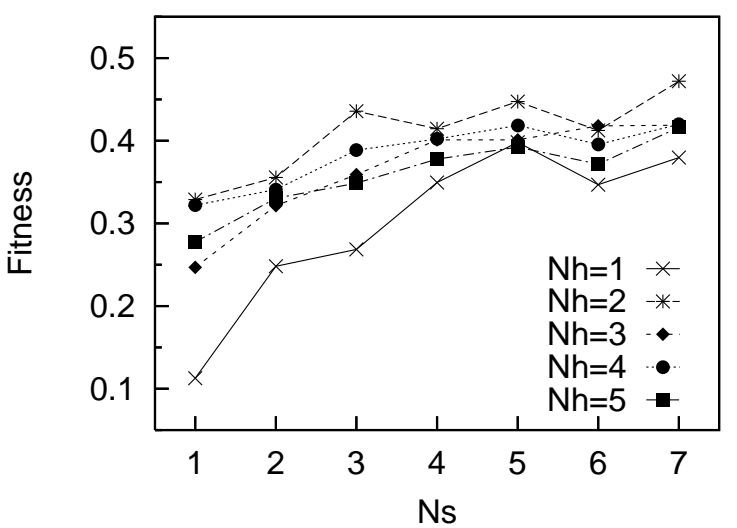

(f) SCEANN 3 by the OGA

Fig. 6 Maximum fitness at the final generation for each coding by the SGA and the OGA for the simulated environment

進化手法として SGAおよびOGAを用いる．ANNの 結合荷重を変数とし，2.で述べたようにコーディングを行 う. 参考文献 [11] と同樣の理由により, 交叉は両 GA とも に用いない . SGA では遺伝的操作として点突然变異のみ を用いる.各SCEANNに対し両 GA ともに点突然変異率 を $1 / L_{n}(n=1,2,3)$ とする.OGA では遺伝的操作として 点突然変異に加えて五つの遺伝的操作を用いる.これらは 結合, 分割, 重複, 欠失, 逆位とよばれ, 各パラメータは $\left(g_{\text {con }}, g_{\text {div }}, g_{\text {dup }}, g_{\text {del }}, g_{\text {inv }}\right)=(0.3,0.3,0.6,0.3,0.3)$
を使用する.OGA は圥長な遺伝子型をもつが , このて長 性を示すリスト長は 6 とする $(\mathrm{OGA}$ の詳細および各パラ メータの推奨値については参考文献 $[10,11]$ を参照). 両 GA ともに，選択法としてトーナメント選択を用い，エ リート戦略を適用する.SGA では弱い選択圧が，OGA では強い選択圧が推奨されていることから，SGA では トーナメントサイズを 2 に，OGA では 6 に設定する [11] . 個体数を 25 , 世代数を 50 とし, 各計算回数を 50 回とす る. 本研究では, 提案手法の有効性を検証するために， 
両 GA ともに各設定を用いた場合の最終世代における最 大適応度を比較する .ここで, 最終世代である 50 世代 より以前の適応度の立ち上がりや 50 世代以降の適応度 の改善の可能性も考えられるが，短いと考え設定する 50 世代の終了時に評価を行う．また実用性を考えた場合， 最終世代で実行可能解を獲得していること(本タスクで はロボットがゴールに到達できること) は, 提案手法の 有効性を検討するときの一つの要点となる .

\section{3 実験結果}

Fig. 6 に，各コーディング法を用いた場合の $\left(N_{s}, N_{h}\right)$ の各組合せに対する各 GA の最終世代における最大適応 度 (50 回平均) を示す. 両 GA ともに, 入カノード数が 増加するほど適応度は増加する傾向にあることがわかる． この傾向が当てはまらない場合 (たとえば，Fig. 6(a)の $N_{s}=7, N_{h}=5$ や, Fig. 6(c) の $\left.N_{s}=6,7, N_{h}=3,4\right)$, 入カノード数の増加により遺伝子長が長くなり探索に時 間かかかることが高い適応度を示さない一因ではないか と推測される.SCEANN 1,2では中間ノード数が減少 するほど適応度は増加する傾向にあるが，SCEANN 3 では逆に $N_{h}=1$ で高い適応度を示さず中間ノード数に 関する傾向は見られない．OGA と SGA を比較すると， $\left(N_{s}, N_{h}\right)$ のすべての組合せでOGA が SGA よりも高い 適応度を示している。

つぎに, 各 GA において比較する. $N_{h}=1,2,3 て ゙ \mathrm{SGA}$ を用いた場合，SCEANN 1 は SCEANN 2,3 よりも高 い適応度を示す．また， $N_{h}=4,5$ に関しては SCEANN 3 が SCEANN 1，2 よりも高い適応度を示す．一方， OGA を用いた場合， $N_{h}=1,3$ に関しては SCEANN 1 はSCEANN 2,3 よりも高い適応度を示す. $N_{h}=2,4,5$ に関してはSCEANN 3 がSCEANN 1, 2 よりも高い適 応度を示す。

Fig. 7 に, 最終世代で最大適応度を示した制御器であ る OGA を用いた SCEANN $3\left(N_{s}=7, N_{h}=2\right)$ を搭載 したロボットの典型的な振舞いを示す . ロボットは初期

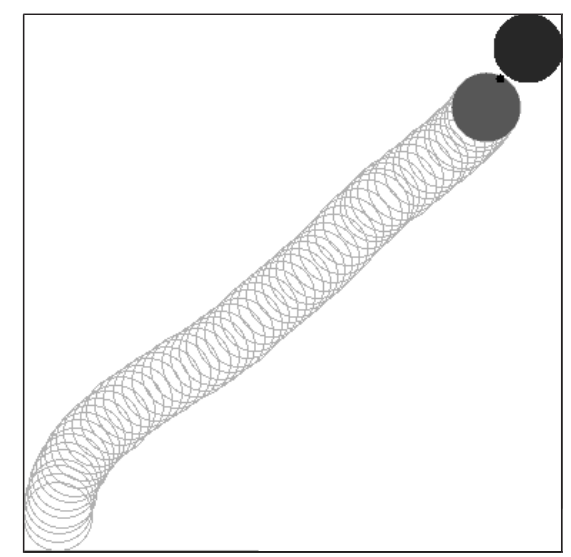

Fig. 7 Behavior of the genetically determined controller for SCEANN 3 with $\left(N_{s}, N_{h}\right)=(7,2)$ by the OGA in the simulated environment
位置で $\theta$ のマイナス方向 (時計回り) に回転しゴール方向 を向き, 弚の後ゴールに向かう．ロボットの振舞いの軌 跡はほぼ直線となる。以上より, 最終世代で得られた制 御器は実行可能解であり，適応度も十分に上がっている と考えられ，提案手法は計算機実験における移動ロボッ トのゴール到達問題に対し有効であることを確認した .

\section{4. 実機実験}

\section{1 タスクと実験環境}

本章では，実機を用いて 3.で得られた知見の有効性を 検証する．タスクおよび基本的な設定は 3. と同じとする . 実験環境を Fig. 8(a)に，実験に用いる移動ロボットを Fig. 8(b) に示す. 実験環境は平面で， $3000 \mathrm{~mm} \times 3000$ mm の正方形であり，周囲は壁で囲まれている . 移動口 ボットは全方位カメラを搭載し, 画像処理とロボットの 制御を行うノート PC を搭載している. 直径 $380 \mathrm{~mm}$, 左右二輪独立駆動型で, 制御器として ANN を用いる. ロボットが全方位カメラ画像を通してゴールとして認識 する目標物の形状は, 赤色の円筒形 (直径 $300 \mathrm{~mm}$ ・高 さ $290 \mathrm{~mm}$ ) とする (Fig. 8(c)) .

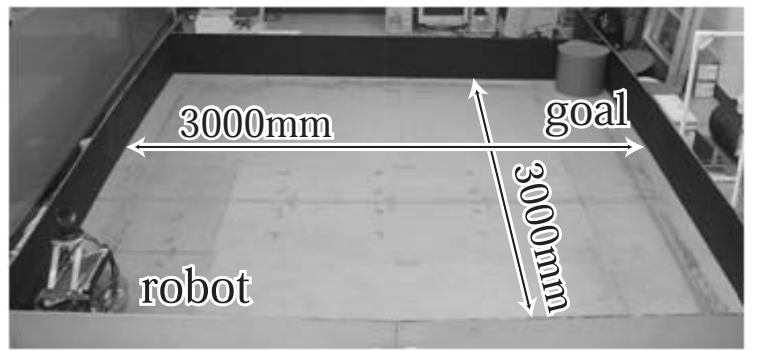

(a) real environment

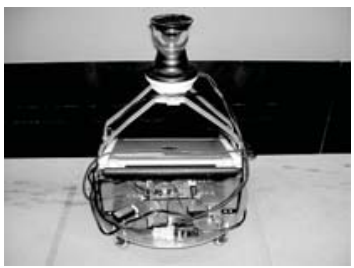

(b) mobile robot

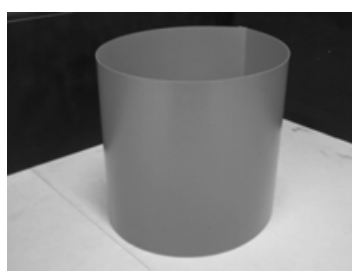

(c) goal
Fig. 8 Experimental setup for a real environment

\section{2 ロボットの入出力設定}

全方位カメラを用いる場合, 一般的に角度情報は信頼 性が高く計算も容易である一方, 距離情報は計算が複雑 になる．しかし，平坦な環境では距離情報は計算が容易 であり [17], 取得した画像の中心から同心円上では, 全 方位カメラの中心からの距離がほぼ一定となる．乥こで， Fig. 9 に示すようにロボットの前方を円周方向に一定の 角度 $\left(\right.$ 約 $\left.13^{\circ}\right)$ で 7 分割し, 半径方向に同心円で 20 分割 する.ここで, 円周方向に 7 分割する理由は, 3. で最も 良い結果を示した制御器の設定 $\left(N_{s}=7\right)$ に合わせるため である.ANNへの入力は以下の画像処理によって決定 される . 


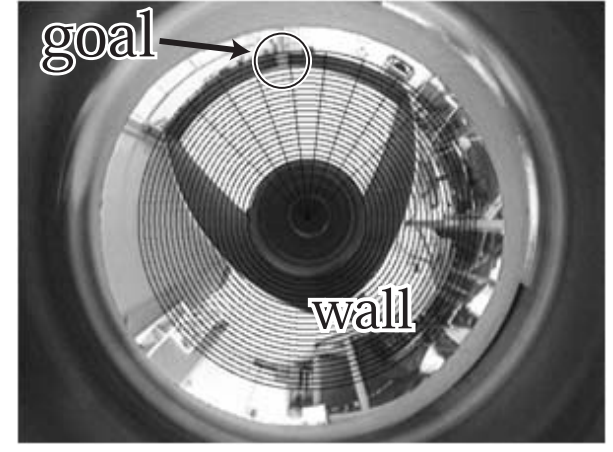

Fig. 9 Omni-directional image plane

(1) 全方位カメラの画像 (Fig. 9) に対し, 目標物の赤 色を抽出するように 2 值化・ラベリングを行い, 分 割された各セルにおける目標物が占める面積 (ピ クセル数) を計算する.

(2) 各円周方向において, 各セルの目標物を示すピク セル数がしきい值 (セル内部のピクセル数の $20 \%$ ) を超えていれば，弚のセルの画像中心からの半径 方向の距離に反比例する值を対応する ANN の入 カノードに与える．ただし，しきい値を超えてい て中心に一番近いセルに関する值を採用する．

ロボットの左右のモータは，PWM制御により乥れ光 れ 40 段階 (前進方向) の速度制御 (デューティ比: $D \in$ $\{61,62, \cdots, 100\}[\%])$ が可能である . 速度指令值である デューティ比は ANN の出力值 $x$ によって次のように 決定される: $D=\left[D_{0}+\left(D_{\max }-D_{0}\right) \times x\right]$. ここで， $D_{0}$ はロボットが移動できる最小のデューティ比で 61 とし， $D_{\text {max }}$ は最大のデューティ比で 100 とする .

\section{3 実験}

\subsection{1 実験設定}

移動ロボットの初期位置および初期姿勢を Fig. 8(a) の環境における左下および右向きに弚れ帒れ設定する . ゴールの位置は右上とする . 各個体につき 1 試行行い , 1 試行はロボットがゴールに到達するか , 40 ステップで終 了とする (1 ステップは約 $1 \mathrm{~s})$. なお ， ロボットのゴール 判定は搭載されている全方位カメラを用いて行う.

ロボットの制御器として，3.て最も良い結果を示した OGA を用いた SCEANN 3 を用いる. 入カノード数は $N_{s}=7$ (ロボットの前方 7 方向，4.2 参照)，中間ノード 数は $N_{h}=2$, 出カノード数は $N_{o}=2$ (モータ数) とする. OGA の設定は 3. と同樣とする .

\subsection{2 実験結果}

世代数に対する OGA の最大適応度と集団の平均適応 度の推移をFig. 10 に示す. 進化初期では, 多くの個体 は初期位置付近の壁で動かなくなり，ゴールに到達でき ず低い適応度を示した．また，実環境における進化のた め，ノイズなどによりエリート個体が前世代と同程度の 適応度を示せないことがあり最大適応度が安定しない． しかし，世代を経ると安定して高い適応度を示すように

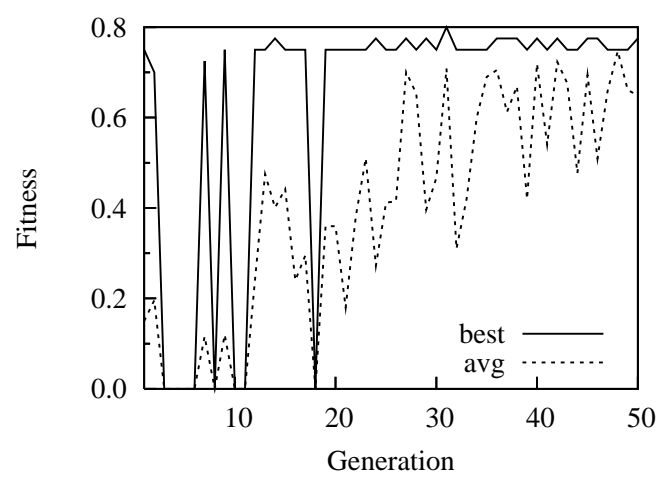

Fig. 10 Fitness at each generation for the real environment

なった . 平均適応度は徐々に増加し集団としても進化し ていることがわかる.また，最終世代までに約 50 時間の 実験時間を要した . 最終世代で得られた最良個体の振舞 いを Fig. 11 に示す.ロボットは，はじめ $\theta$ のプラス方 向 (反時計回り) に緩やかなカーブを描き (1)-(4)), 徐々 に急カーブを描き (5)-8) , 兴の後ゴールに向け直進し ている(9)-(10)）．以上より，最終世代で得られた制御器 は実行可能解であり, 適応度も十分に上がっており, 進 化時間も現実的な時間に納まっていることから，3. で得 た知見が実機実験でも有効であることを確認した .

\section{5. おわりに}

ロボットを実環境で進化させるには膨大な時間がかか る.本論文では，この実時間を短縮するために, 人工進 化が解くべき問題の探索空間をできるだけ小さくするこ とを目的として, 進化型人工神経回路網の簡易コーディ ング法を提案した．乥して，ロボット制御問題の一つで ある移動ロボットのゴール到達問題に対し，2 種類の GA を適用し，光の性能を計算機実験および実機実験により 検証した．得られた結果について次にまとめる．

・どのコーディング法を用いても，入カノード数が増 加すると最終世代の適応度は高くなる．

- SCEANN 1 は, 中間ノード数が小さい場合に高い 適応度を示す。

- SCEANN 3 は, 比較的中間ノード数が大きい場合 に高い適応度を示す。

- 各入力・中間ノード数の組合せに対し, OGA を適 用したSCEANN はSGA の光れよりも高い適応度 を示す。

- 実機実験において, 計算機実験で得られた知見が有 効であることを確認した .

以上より, 提案するSCEANN は, 移動ロボットのゴー ル到達問題に対し, 適応度および進化時間の観点から有 効であることを確認した . 提案手法によって獲得される ANN の構造は非常に簡単なものになるため, ロボット の振舞いをニューロンレベルで解析することが可能にな るのではないかと期待される . 


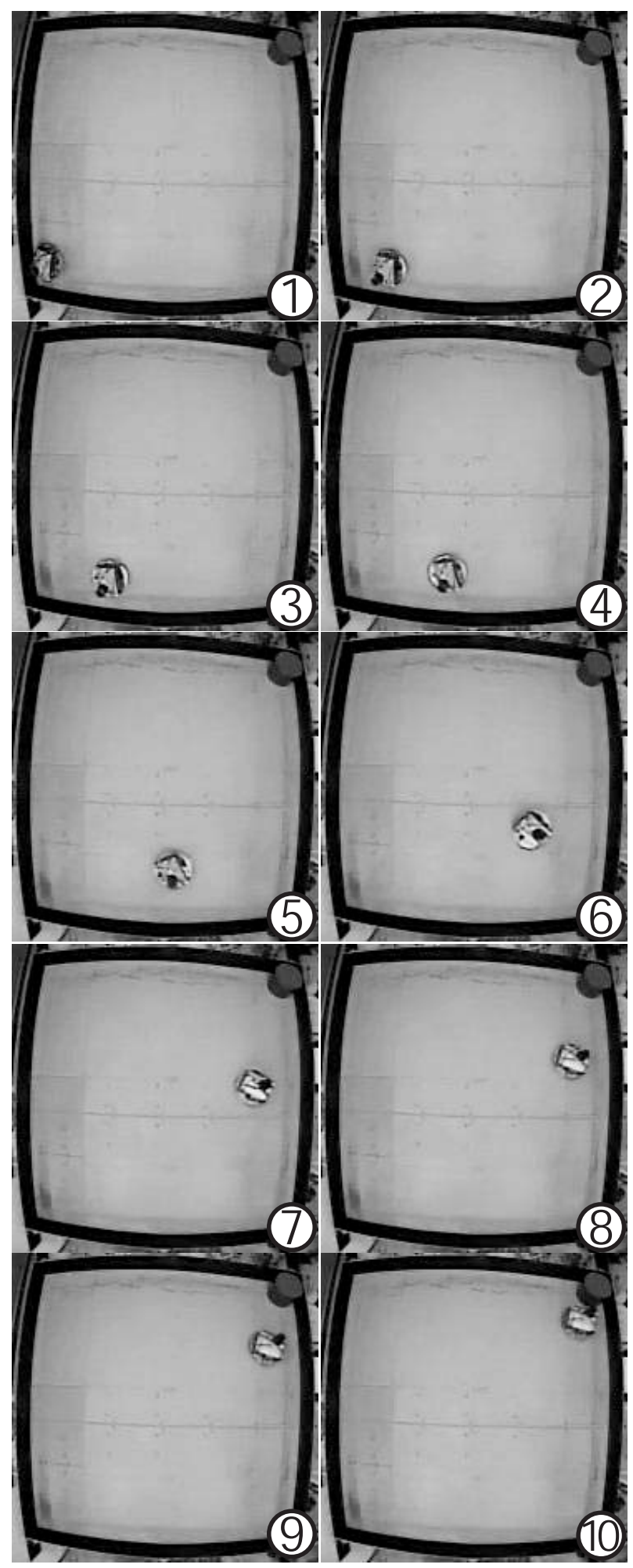

Fig. 11 Behavior of the genetically determined controller for $\operatorname{SCEANN} 3$ with $\left(N_{s}, N_{h}\right)=(7,2)$ by the OGA in the real environment

一方で, 提案手法は設計変数の定義域を非常に粗く コーディングしていることになるため, 設定する探索空 間が問題の実行可能解を含まない可能性がある . 今後 , 他のロボット制御問題に適用し，本手法の有効性および 限界をさらに検証する予定である . また, 本手法は遺伝
子長が非常に短くなることから，マルチロボットのコン トローラすべてを一つの遺伝子型にコーディングする場 合 [18]にも有効であると予想されるため，これについて も検証したい.

\section{参 考 文 献}

[1] R. Pfeifer and C. Scheier: Understanding Intelligence, MIT Press (1999)

[2] S. Nolfi and D. Floreano: Evolutionary Robotics: The Biology, Intelligence, and Technology of SelfOrganizing Machines, MIT Press (2000)

[3] R. A. Watson, S. G. Ficici and J. B. Pollack: Embodied evolution: Embodying an evolutionary algorithm in a population of robots; Proceedings of Congress on Evolutionary Computation, pp. 335-342 (1999)

[4] N. Jakobi: Half-baked ad-hoc and noisy: Minimal simulation for evolutionary robotics; Proceedings of the Fourth European Conference on Artificial Life, pp. 348-357 (1997)

[5] R. A. Brooks: Artificial life and real robots; Proceedings of the First European Conference on Artificial Life, pp. 3-10 (1992)

[6] O. Miglino, H. H. Lund and D. Nolfi: Evolving mobile robots in simulated and real environments; Artificial Life 2, pp. 417-434 (1995)

[7] 高崎, 片田, 大倉 , 田浦: 進化型自律移動ロボットの才 ンラインモデル更新に関する一手法; 第 47 回自動制御連 合講演会, CD-ROM 予稿集, 404 (2004)

[8] D. Floreano and C. Mattiussi: Evolution of spiking neural controllers; Evolutionary Robotics: From Intelligent Robots to Artificial Life (ER'01) (T. Gomi, ed.), AAI Books, Springer-Verlag, pp. 38-61 (2001)

[9] J. C. Zufferey, D. Floreano, M. van Leeuwen and T. Merenda: Evolving vision-based flying robots; 2nd International Workshop on Biologically Motivated Computer Vision (BMCV'2002), Lecture Notes in Computer Science, pp. 592-600 (2002)

[10] 大倉, 上田: 中立突然変異型 GA による騙し問題の最適 化; 計測自動制御学会論文集, Vol. 32 , No. 10, pp. 14611469 (1996)

[11] 片田, 大倉 , 上田: Neutral Networks を含む適応度景観 における遺伝的アルゴリズムの進化ダイナミクス; シス テム制御情報学会論文誌, Vol. 17, No. 5, pp. 187-195 (2004)

[12] 片田, 大倉: ニュートラルネットワークを含む適応度景 観における遺伝的アルゴリズムの進化ダイナミクス -進 化ロボティクスでの検証; システム制御情報学会論文誌, Vol. 21 , No. 2 , pp. 31-39 (2008)

[13] X. Yao: Evolving artificial neural networks; Proceedings of the IEEE, Vol. 87, No. 9, pp. 1423-1447 (1999)

[14] S. Abe: Pattern Classification: Neuro-Fuzzy Methods and Their Comparison, Springer-Verlag (2001)

[15] W. Maass and C. M. Bishop: Pulsed Neural Networks, MIT Press (1998) 
[16] 小森谷, 大山 , 谷: 移動ロボットのためのランドマーク 観測計画; 日本ロボット学会誌, Vol. 11, No. 4, pp. 533540 (1993)

[17] 森，家田，松井: 全方位移動機構と全方位視覚を有する 小型ロボットによるサッカー競技の実現—チーム OMNI の戦略一; 人工知能学会 第 6 回 SIG-Challenge 研究会 論文集, Vol. 1, pp. 42-47 (2000)

[18] 片田，西村: 進化型マルチェージェントによる協調荷押 し行動獲得に関する一考察; 第 52 回システム制御情報学 会研究発表講演会論文集, pp. 469-470 (2008)

\section{著者略歴}

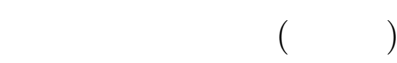

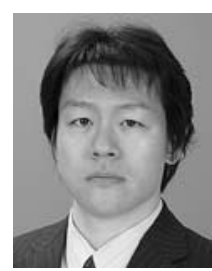

1975 年 7 月 15 日生. 1999 年 3 月神戶大 学工学部機械工学科卒業, 2004 年 9 月同 大学大学院自然科学研究科博士後期課程修 了. 2005 年 4 月捸南大学工学部電気電子 工学科講師，2009 年 4 月同准教授となり， 現在に至る.進化型計算, 進化ロボティク ス, ロボットハンドの研究に従事. 博士 (工学) . 2009 年イン テリジェント・システム・シンポジウム発表賞受賞 .計測自動 制御学会, 日本ロボット学会, 電気学会, IEEEなどの会員.

皆防拓哉

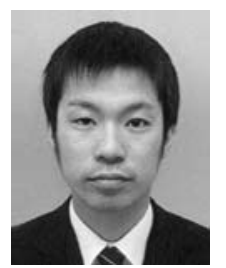

1986 年 5 月 29 日生. 2009 年 3 月捸南大 学工学部電気電子工学科卒業. 同年 4 月中 央電設 (株) 入社, 現在に至る。在学中は 進化ロボティクスの研究に従事. 